\title{
Pitfalls and Possibilities of Patinated Bronze: The Analysis of Pre-Roman Italian Armour Using pXRF
}

\author{
Joshua Emmitt ${ }^{1, * \mathbb{D}}$, Andrew McAlister ${ }^{1}$ and Jeremy Armstrong ${ }^{2}$ \\ 1 School of Social Sciences, University of Auckland, Auckland 1010, New Zealand; \\ andrew.mcalister@auckland.ac.nz \\ 2 Classics and Ancient History, University of Auckland, Auckland 1010, New Zealand; \\ js.armstrong@auckland.ac.nz \\ * Correspondence: josh.emmitt@auckland.ac.nz
}

\section{check for} updates

Citation: Emmitt, J.; McAlister, A.; Armstrong, J. Pitfalls and Possibilities of Patinated Bronze: The Analysis of Pre-Roman Italian Armour Using pXRF. Minerals 2021, 11, 697. https://doi.org/10.3390/min 11070697

Academic Editors: Daniel

Albero Santacreu, José

Cristóbal Carvajal López and

Adrián Durán Benito

Received: 10 June 2021

Accepted: 25 June 2021

Published: 29 June 2021

Publisher's Note: MDPI stays neutral with regard to jurisdictional claims in published maps and institutional affiliations.

Copyright: (c) 2021 by the authors. Licensee MDPI, Basel, Switzerland. This article is an open access article distributed under the terms and conditions of the Creative Commons Attribution (CC BY) license (https:// creativecommons.org/licenses/by/ $4.0 /)$.

\begin{abstract}
Despite the importance of weapons and armour as part of material culture in the Mediterranean during the first millennium $\mathrm{BCE}$, such objects have generally not been studied beyond stylistic analyses. Bronze was extensively used in the construction of these materials; however, its characterisation is complicated due to patination and the different manufacturing techniques used. We used portable XRF ( $\mathrm{pXRF}$ ) to non-destructively characterise bronze material in a way that mitigates the distorting effects of patina. Analysis was conducted on 23 pieces of pre-Roman Italian bronze armour. Assays were taken using two different techniques; 'single point' assays and 'cluster' assays. There is variability visible across assays both on and between items, grouped both geographically and chronologically. We highlight significant trends visible in the results over time and different object types and discuss the utility of pXRF on ancient bronze with recommendations for best practice.
\end{abstract}

Keywords: Italy; military equipment; bronze; pXRF; museum collections; non-destructive analysis

\section{Introduction}

Given the generally accepted cultural significance of weapons and armour within the societies of the ancient Mediterranean during the first millennium BCE (e.g., [1,2]), it is perhaps surprising that the actual physical properties of weapon and armour finds from this region and period remain largely unexplored by modern scholars. Although long studied for their stylistic and artistic merits, very few analyses have been conducted on the physical nature and composition of equipment finds from the ancient Mediterranean during the first millennium BCE beyond the recording of their basic dimensions and the identification of material used, which are typically described as simply 'bronze' or 'iron' (e.g., [3-5]; notable exceptions include [6,7], see [8] for discussion, and more recent work [9]). This is despite the fact that the ancient literary sources themselves explicitly discuss the use of different types of alloys in the production of items-most notably Pliny (esp. NH 34) but also Cicero (Tusc. Disp. 4.32) amongst others-and the obvious differences in technology, construction, and performance which the use of different alloys and materials would entail. Admittedly, the lack of work in this area is partly due to the relative difficulty in analysing such objects, as we discuss below. The items under investigation are often heavily patinated, repaired, or conserved, and the vast majority of ancient military equipment finds have long been housed in museums and private collections, which necessitates the use of non-destructive analytic methods. However, this has not stopped others (e.g., [10]) from exploring similar issues in earlier weapons and armour from the European Bronze Age.

The elemental characterization of military equipment has the potential to reveal variations in manufacturing processes over time and space as well as differences between and within specific categories of items (e.g., helmets, cuirasses, etc.). Comparison of elemental compositions across an object, and on its different components, may also highlight how different alloys were used in the manufacturing process. Likewise, comparison of the 
elemental compositions of objects in a particular depositional context (such as a tomb), between different tomb assemblages, and between different regions, may identify local and regional variations as well as indicate trade and distribution patterns. Differences in production techniques may be observed, as well as the differential sourcing of materials and changes in material use over time. Variations in these processes have the potential to inform on the nature, development, supply, and maintenance of bronze military equipment.

To this end we examine military equipment from the Gaudo Necropolis (Paestum), Necropoli dell'Osteria (Vulci), Necropoli di Malpasso (Gualdo Tadino, Umbria), Casal del Fosso (Veii), Cava della Pozzolana (Ceveteri) (Figure 1) to explore these issues in central Italy from c. $900-300 \mathrm{BCE}$.

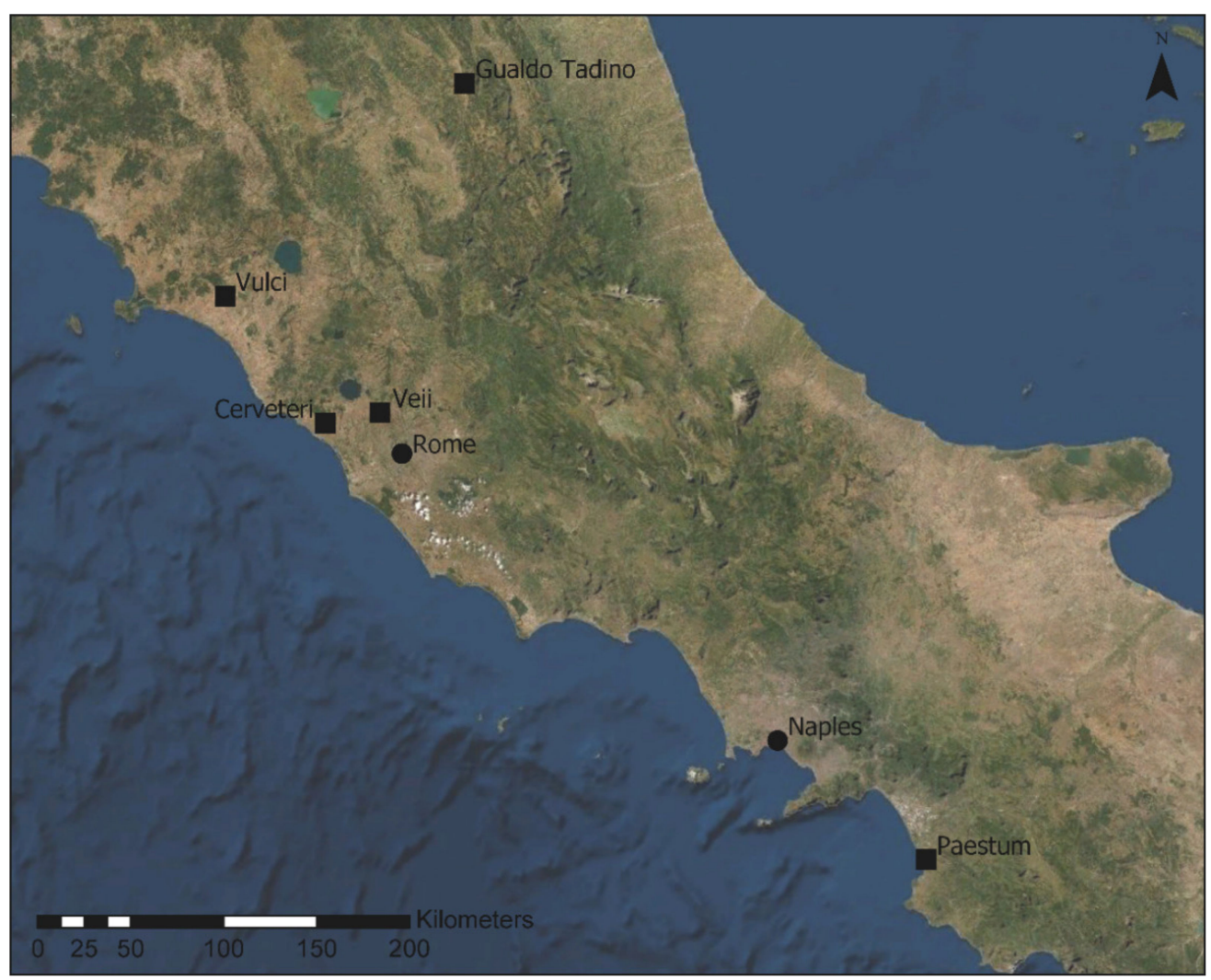

Figure 1. Location of the provenances where military equipment examined in this paper are from (Squares) and the location of Rome and Naples for reference (Circles).

\section{Elemental Characterization of Bronze}

As noted above, non-destructive characterization of bronze alloys (defined here as being composed of predominantly copper $(\mathrm{Cu})$ and tin $(\mathrm{Sn})$, typically with other trace elements) from archaeological contexts is notoriously difficult, primarily because nondestructive techniques are limited to analyses near the surfaces of objects, which often are patinated. Patina has a different elemental signature from the base metal it forms on, and its formation varies over time; starting fast, gradually slowing, and eventually stabilizing [11]. The composition of patina is variable, depending on original composition of the metal and the post-depositional environment, and is formed when an alloy is exposed to the corrosive effects of soil, water, and air. The chemical composition of the depositional environment, its $\mathrm{pH}$ level, and resistivity all play a part in its formation, as does the thickness of the alloy and how it was formed. The formation of patina alters the elemental signature of the alloy in a number of ways, and specifically the structure of the surface, the form of which is influenced by the aforementioned factors [11]. Most notably, the formation of patina can often result in depletion of copper and the surface enhancement of a range of other 
elements pulled from both the depositional environment and the core metal [12]. Due to the patination process, elements such as Sn often appear in increased percentages in surface readings, even on cores/bases which were initially composed of medium-to-low Sn alloys. Indeed, $\mathrm{Sn}$ at the surface can sometimes reach levels comparable to those found in items that had undergone tinning, therefore rendering the two processes indistinguishable from each other [11,13-15]. Patinas also often vary across a single object, forming localised or non-uniform areas of corrosion due to a range of different factors related to both the alloy and the depositional context [16].

Another related factor which complicates this sort of work is the fact that ancient bronzes are themselves rarely uniform in composition [17,18], even within a single item (let alone across a context, site, or culture), and often feature a complex array of trace elements found in varying ratios across the item. Trace elements can also be introduced in a range of different ways. In a study of ancient copper, and the potential analyses of it to determine provenance, Pernicka [19] investigated changes in trace elements during the smelting processes. Elements were classified as either remnants from the original ore, a result of metallurgical practices (incl. patination), or a combination of the two [20]. Elements such as iron (Fe) and sulphur (S) can either be a result of the smelting process, intentional additions, or form part of a corrosion layer during deposition [19]. Lighter elements, such as oxygen $(\mathrm{O})$, carbon $(\mathrm{C})$, and chlorine $(\mathrm{Cl})$, were found to relate to corrosion processes (i.e., patina formation). Elements like $\mathrm{Sn}$ are often overrepresented as a result of patination and studies have also demonstrated that concentrations of other elements, such as Fe, reduce when copper is re-melted and recycled [21,22]. The aim of the studies by Pernicka and Merkel was to investigate the feasibility of determining the provenance of different copper sources by elemental composition alone, which could be used to discuss larger processes of resource availability and trade and exchange. Complications caused by patination, both on the surface and in the core of the metal, meant that this was largely ineffective and there are more suitable methods, such as lead isotope analysis, that can be used for these purposes (e.g., [23]). However, the work of Pernicka and Merkel clearly demonstrates the range of issues and complexities which arise during all stages of the life-cycle of, not only a bronze artefact, but also the ore it is made from and where and how it is deposited. Further, the widespread evidence for the recycling of bronze items in the ancient Mediterranean, and particularly Italy [24], complicates provenancing items by elemental signature and hints that this sort of analysis may only be useful for very specific artefacts and contexts.

Due to the issues caused by patina, elemental characterization of bronze alloys has therefore often been a destructive process, where items are cleaned to remove the patina or the item is cut or drilled to access the core or 'base alloy' (e.g., [25]). As is often the case and often cited as the case (e.g., [23]), the destructive sampling of objects from antiquity is not possible (or indeed desirable) due to the aesthetic value of the object, or indeed the object's integrity, both physically and as an excavated item existing in its modern context. The value of destructive analysis is therefore often debatable and its utility certainly depends on what the investigator wishes to discover, as well as the nature of the object itself. For artefacts made from thin bronze sheets, there may be little effective difference between destructive and non-destructive, 'surface based' techniques. Patinas often form quickly on exposed bronze, reaching thicknesses of $0.1 \mathrm{~mm}$ within the first three months, although slowing in subsequent periods, only reaching $0.13 \mathrm{~mm}$ after two years [26]. Additionally, while patinas start on the surface, they are not strictly surface phenomena and typically penetrate the metal along grain boundaries and may ultimately convert the entire core to cuprite [27] (p. 5). This is particularly true for thin sheets (under $0.5 \mathrm{~mm}$, which is typical for archaic bronze armour), with the result that there often appears to be no untouched core of metal left to test even if destructive techniques were employed. Perhaps ironically, to confirm this, destructive metallographic analyses would need to be carried out.

PXRF has increasingly been touted as a quick, affordable, non-invasive, surface-based technique, which might be able to provide a non-destructive method by which to elementally characterise an object. As a consequence, it has been regularly deployed in a wide 
range of situations (e.g., $[25,28,29]$ etc.). This work is complicated by the aforementioned difficulties in determining what is being measured, the patina or core metal, and in determining a measure from the 'original' surface of the object. Indeed, it is clear that for many bronze items, and for many research questions (which require any degree of objective specificity in the results), pXRF is decidedly ill-suited [30]. However, as Pearce noted in his critique of the wider use of pXRF on corroded bronze, "portable XRF is a useful tool for the preliminary analysis of metal artefacts" ([30], p. 84). Similar issues have previously been raised with the use of pXRF on other materials which largely argue between 'scientific precision' versus internal consistency of readings, which can still be deployed in pursuance of appropriate research questions (see debate between [31,32] for an example with obsidian sourcing). Further, depending on the items being investigated and their level of patination, the benefits of destructive techniques over pXRF can also vary.

As pXRF analyses are often carried out on unmodified artefact surfaces, the results do not necessarily represent the bulk composition of the core metal alone but also include the composition of surface patinas, which can vary considerably in extent. When compared to other methods, such as multicollector inductively coupled plasma mass spectrometry (MC-ICP-MS) and electron probe microanalyser (EPMA), the measurement of some materials, such as copper, by pXRF has still demonstrated similar accuracy under certain conditions $[23,28,33,34]$. Cleaned copper has shown to provide similar results between destructive methods and pXRF [23,28]. Dussubieux and Walder [34] were able to distinguish American native copper from European copper fragments using pXRF alone and on uncleaned surfaces. Some success has also come with the use of pXRF through the implementation of Monte Carlo simulations, as a way to circumvent the effects of patina [35-39]. Monte Carlo simulations are often tested on experimental data and, when implemented on artefacts, are accompanied by a contrasting destructive analysis. The issue with the implementation of Monte Carlo simulations is that it currently still requires knowledge of the cross-section of a corroded alloy. The thickness and composition of a patina are required to simulate the original bronze alloy [36]. In the absence of a comparative assay taken on a clean surface, it is not possible to verify the results of the analysis. One is effectively comparing a surface reading with a hypothesised ideal reading, without any firm way to confirm the hypothesised ideal is correct. Future work may remove this barrier, but as yet it does not provide the answer to the long-standing issue of patination.

Another approach to the issue of elemental characterisation of bronze alloys with pXRF, and in particular bronze alloys with varying degrees of patina, is to examine the signatures from the patina itself [40]. The aim of such an analysis is to investigate what the patina can say about the post-depositional environment of the artefacts. With enough data about the patina, and enough readings from the item, it may be possible to 'filter out' or compensate for this layer of material to achieve at least a qualified and comparative set of results. The risk with such an approach is that equifinality arguments are likely, but in such cases more information is known than was previously. Given patina and cuprified material forms the vast majority, if not totality, of many of the thin items explored, in addition to the fact that the items are currently housed in museums and private collections and were therefore unavailable for destructive sampling, we apply such an approach here. However, as will be described, within this approach some methodologies are more illuminating than others.

\section{Case studies}

Twenty-three items of bronze armour were examined, from nine contexts that come from five sites across central and southern Italy (Figure 1, Table 1). The objects are dated between 750-350 BCE (Table 2) and generally come from what may be considered as primary sealed contexts (i.e., tombs). Little is known about the specific provenance of most of the objects beyond what is reported here, and, as is often the case, the details which do exist do not include sufficient information about the specific depositional contexts in 
which the objects were found to make informed inferences regarding the formation of their patinas.

Table 1. Provenances and descriptions of the objects analysed.

\begin{tabular}{|c|c|c|c|c|}
\hline Site & Tomb & Item(s) & Date (BC) & Location \\
\hline \multirow{3}{*}{$\begin{array}{l}\text { Paestum/Poseidonia: Gaudo } \\
\text { Necropolis [41-44] }\end{array}$} & $\begin{array}{l}\text { Tomb 136: Male, } 25-30 \text { y/o } \\
\text { Figure S1.1 }\end{array}$ & - $\quad$ Triple disc cuirass (P001). ID\#: 103957 & $420-400$ & \multirow{3}{*}{$\begin{array}{l}\text { National Archaeological } \\
\text { Museum of Paestum }\end{array}$} \\
\hline & $\begin{array}{l}\text { Tomb 164: Male, } 17-20 \text { y/o } \\
\text { Figures S1.2-6 }\end{array}$ & $\begin{array}{ll}- & \text { Samno-Attic Helmet (P005) ID\#: } 104106 \\
- & \text { Triple disc cuirass (P004). ID\#: } 104110 \\
- & \text { Belt (P006). ID\# 104108 } \\
-\quad & \text { Left greave (P003) ID\# 104110 } \\
& \text { Right greave (P002) ID\# } 104110\end{array}$ & \multirow[t]{2}{*}{$380-370$} & \\
\hline & $\begin{array}{l}\text { Tomb 197: Adult male } \\
\text { Figure S1.7 }\end{array}$ & - $\quad$ Triple disc cuirass (P008) ID\#: 104376 & & \\
\hline $\begin{array}{l}\text { Cerveteri: Cava della } \\
\text { Pozzolana }[45,46]\end{array}$ & $\begin{array}{l}\text { Tomb } 72 \\
\text { Figure S1.12 }\end{array}$ & - $\quad$ Belt (VG006) ID\#4999 & c.700 & \multirow{6}{*}{$\begin{array}{l}\text { National Etruscan } \\
\text { Museum of Villa } \\
\text { Giulia, Rome }\end{array}$} \\
\hline $\begin{array}{l}\text { Gualdo Tadino, Umbria: } \\
\text { Necropoli di Malpasso [47] }\end{array}$ & $\begin{array}{l}\text { Tomb } 12 \\
\text { Figure S1.9-11 }\end{array}$ & $\begin{array}{ll}- & \text { Negau Helmet (VG002) ID\# } 44429 \\
- & \text { Negau Helmet (VG003) ID\# } 44430 \\
- & \text { Seven pieces of a single shield } \\
\text { boss / decoration (VG004a-g) ID\# } 44434\end{array}$ & $400-350$ & \\
\hline \multirow[b]{2}{*}{ Veii: Casale del Fosso [48-50] } & $\begin{array}{l}\text { Tomb 871 } \\
\text { Figures S1.18-19 }\end{array}$ & $\begin{array}{ll}- & \text { Crested helmet (VG015) ID\#61913 } \\
\text { - } & \text { Shield (VG013) ID\#36455 }\end{array}$ & $730-720$ & \\
\hline & $\begin{array}{l}\text { Tomb } 1036 \\
\text { Figure S1.17,20-23 }\end{array}$ & $\begin{array}{ll}\text { - } & \text { Crested helmet (VG012) } \\
\text { - } & \text { Armour discs (VG016, VG019) } \\
\text { ID\#37391-2 } \\
\text { - } \quad \text { Composite shield (VG017, VG018) } \\
\text { ID\#37393-6 }\end{array}$ & $750-730$ & \\
\hline \multirow[t]{2}{*}{$\begin{array}{l}\text { Vulci: Necropoli } \\
\text { dell'Osteria [51] }\end{array}$} & $\begin{array}{l}\text { Tomb } 47 \\
\text { Figures S1.13-16 }\end{array}$ & $\begin{array}{ll}- & \text { Negau helmet (VG010) ID\#63579 } \\
- & \text { Left greave (VG008) ID\#63575 } \\
- & \text { Right greave (VG009) ID\#63575 } \\
\text { - } & \text { Shield (VG011) }\end{array}$ & $530-510$ & \\
\hline & $\begin{array}{c}\text { Tomb } 55 \\
\text { Figure S1.8 }\end{array}$ & $\begin{array}{l}\text { - Etrusco-Thracian helmet (VG001) } \\
\text { ID\#63688 }\end{array}$ & $400-350$ & \\
\hline
\end{tabular}

Table 2. Location and date of the different tomb assemblages examined here across time.

\begin{tabular}{|c|c|c|c|c|c|c|}
\hline \multirow{2}{*}{$\frac{\text { BCE }}{750}$} & Paestum & \multirow[t]{2}{*}{ Vulci } & \multirow[t]{2}{*}{ Gualdo Tadino } & \multicolumn{2}{|c|}{ Veii } & \multirow{2}{*}{$\begin{array}{c}\text { Cerveteri } \\
\text { Tomb } 72\end{array}$} \\
\hline & & & & Tomb 871 & Tomb 1036 & \\
\hline \multicolumn{7}{|l|}{700} \\
\hline \multicolumn{7}{|l|}{650} \\
\hline \multicolumn{7}{|l|}{600} \\
\hline 550 & & Tomb 47 & & & & \\
\hline \multicolumn{7}{|l|}{500} \\
\hline 450 & Tomb 136 & & & & & \\
\hline 400 & Tomb 164 & Tomb 55 & Tomb 12 & & & \\
\hline 350 & & & & & & \\
\hline
\end{tabular}

Most of the objects examined were made from a single piece of bronze, although some (most notably helmets) featured some additions. These include decorative pieces, flanges, cheekpieces, and attachments which may be of a different material, or attached via a different material (e.g., solder) but these are visually distinguishable. Cuirasses represent a rather different set of items as well, as they are consistently composed of multiple large pieces (e.g., front and back plates, along with shoulder straps, side plates, etc.), and the materials and alloys of the different components may be different. In addition, clasps, hooks, rings, and rivets may all have slightly different compositions. This creates another potential complication when distinguishing the compositions of metal objects, as when variability is sought between assemblages, it first needs to be investigated across single objects. Museum identification numbers were also often found to be insufficient to clearly 
identify the objects, as a single item may have no clear identification number or multiple numbers depending on how and when it was found, reconstructed, and classified. Many items are conventionally described in scholarship using tomb contexts and not museum inventory number. Identifiers localised to this study were assigned to each object and are presented in Table 1 with the provenance information for the objects and museum identification numbers where possible. Objects are patinated to varying degrees, which caused some issue during the analysis and is discussed with the results below. It was not possible to clean or destructively sample the objects that were examined, and as discussed it is questionable what merit there would be in doing so.

\section{Methods}

In this study we used a Tracer III-SD portable X-ray Fluorescence (pXRF) analyser (Bruker, Billerica, MA, USA; see Appendix A for calibration details, Supplementary Materials for the locations of assays on each object). PXRF assays were taken for $60 \mathrm{~s} \mathrm{each,} \mathrm{and}$ their locations were recorded on annotated photographs and transcribed to a photogrammetric model of each object. At the first level, assays were compared across single objects. This involved the analysis of a combination of single assays as well as clusters of five assays (as proposed by Ferretti [52]) that were taken in a circular fashion across a $1 \mathrm{~cm}$ diameter circle on an object (Figure 2). The aim of these cluster assays was to measure variation over a relatively contained surface area, where both the core metal and depositional conditions should have been largely consistent. Microscale heterogeneity remains a problem with any ancient bronze alloy, and this type of approach falls into the category of "area mapping", as proposed by Karydas et al. [53], to ascertain mean values of elemental intensities across an area. Assays were targeted at the cleanest areas possible (i.e., those with perceived low surface roughness caused by patina) and other areas of interest, as determined from a visual analysis, including decorative sections, rivets, areas of potential repair, rings, and separate sheets of metal.

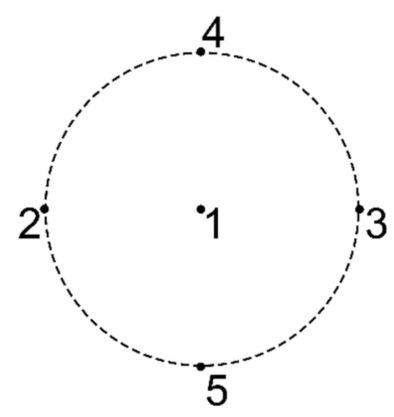

Figure 2. Example of a cluster of five assays and the order they were recorded in. The circle is $1 \mathrm{~cm}$ in diameter. This is represented as a cross-hair symbol on object figures.

\section{Results}

The results of each assay are presented by item and location in Table S1, with accompanying figures in the Supplementary Materials Figure S1 for where assays were taken on each object. Due to the heterogeneous nature of the artefacts in their current state, the percentages of the elements recorded do not add up to $100 \%$. Cu-Sn bronzes develop patinas consisting of various copper salts which feature significant amounts of carbon (C) and oxygen $(\mathrm{O})$, along with chlorine $(\mathrm{Cl})$ amongst other elements [54]. These elements are not within the detectable limits of current pXRF devices. In addition, patinas are not only surface phenomena and alter the elemental signature of the metal, a point we return to below. As a result, even given what might be considered 'almost optimal' conditions, between 4 and $20 \%$ of the elements in the material will not be calibrated for. Working on the assumption that uncalibrated elements must be part of the patina requires caution as the character of the 'actual bronze' being measured can be skewed by both the calibration standards used and the underlying assumptions of the normalization. 
Data from the patinated items from museum collections suggests that patina might account for up to $70 \%$ of the elements in some assays, and this fact very likely skews the remaining elements as well. Some measurements provided an even lower total percentage, although these were from areas which were visually identifiable as being composed of other elements, often $\mathrm{Fe}$ rivets or $\mathrm{Pb}$ attachments.

An interesting feature of the study was the variation visible in the measurements across each item. This confirms the work from other studies on ancient bronzes (e.g., [18]) which shows ancient bronze items, and particularly weapons and armour, typically do not have uniform compositions - even across a single item. It is noteworthy, though, that the vast amount of the variability occurred in the levels of $\mathrm{Cu}$ identified in each assay, which likely relates to cuprification. Levels of other key elements, most notably $\mathrm{Sn}, \mathrm{Pb}, \mathrm{Fe}$, zinc (Zn), and arsenic (As), stayed largely stable within clusters.

It is clear that increased levels of patina exacerbated many of the factors visible in the assays on relatively clean items - albeit in largely predictable ways. Looking at the total amount of material which fell within the calibrated elements, this varied by wider amounts depending on the amount and type of patina on the items, ranging up to $40 \%$ on a single item. However, again, the vast majority of this variation was due to the amount of $\mathrm{Cu}$. Other elements stayed largely stable, varying by less than $2 \%$, across individual pieces of bronze, for all elements except for tin (Sn). Measurements for tin (Sn) varied by up to c. 10\% across single pieces. Although, much of this may have been due to the impact of patination and readings from assay clusters typically revealed more stable numbers (within a range of $+/-3 \%$ from the average), which is supported by results from comparable studies [55].

\section{Cluster Assays}

Values for the cluster assays are the mean values of the five readings in each cluster. Only elements determined 'stable' across the item and by the calibration were used in this process; $\mathrm{Mn}, \mathrm{Fe}, \mathrm{Zn}, \mathrm{As}, \mathrm{Sn}, \mathrm{Pb}$. Copper was found to be too variable across objects in both percentage and composition. It was concluded that $\mathrm{Cu}$ is affected too much and too variably by patina formation, and so was excluded from the analysis of the cluster assays.

The cluster assays provide a method by which the relative homogeneity of the material may be identified. Again, it must be noted that these readings include the patina and are not strictly a result of the base of metal, however, given the thinness of the items (c. $0.1 \mathrm{~mm}$ ) they can be taken as roughly indicative of patina and base combination. The analyses show low variation within each cluster, demonstrating the roughly homogenous nature of the materials (patina and base), with the exception of one. One example from P004 (P004_4-assays 23-27) has three of the five assays with relatively homogenous readings, and two have higher Fe concentrations (Figure 3). In the case of P004_4, the remains of a visually identified rivet were the target of analysis, but the area was so small that multiple readings were undertaken. The fortuitous result being that the assays which 'missed' the rivet resulted in the identification of it due to their differential composition.

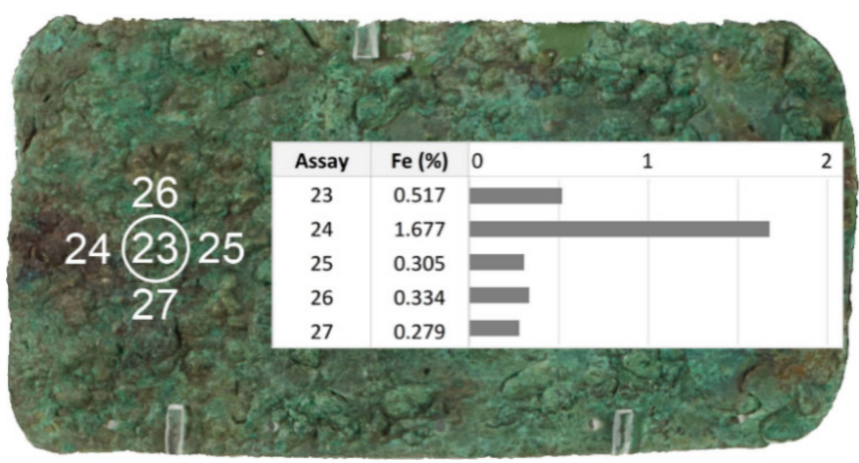

Figure 3. Location of cluster assay P004_4 (assays 23-27) on the right flap of P004 with values of Fe. 
The cluster assays can also help to reveal modern interventions. On item VG013, a heavily reconstructed shield from tomb 871 of the Casale del Fosso necropolis at Veii, individual $(6,13-16)$ and cluster assays (1-5) revealed a markedly different material, featuring much higher levels of $\mathrm{Pb}$ and much lower levels of $\mathrm{Sn}$, from that measured by most of the various single assays $(7-12,17)$ taken at other points on the artefact (Figure 4). This particular area encompassed by assays 1-5 was targeted for a cluster of assays as it appeared to be, from an initial visual examination, a roughly representative section of the artefact. However, upon reviewing the totality of the results, alongside macro photography and earlier publications, it was clear that it was likely in fact a heavily reconstructed section, along with assays 6 and 13-16 (Grey in Figures 4 and 5). For this reason, this particular cluster, as well as others shown to group with it, has been removed from the wider analysis of ancient materials, although it is illustrative of the effectiveness of pXRF for identifying modern repair (Figure 4).
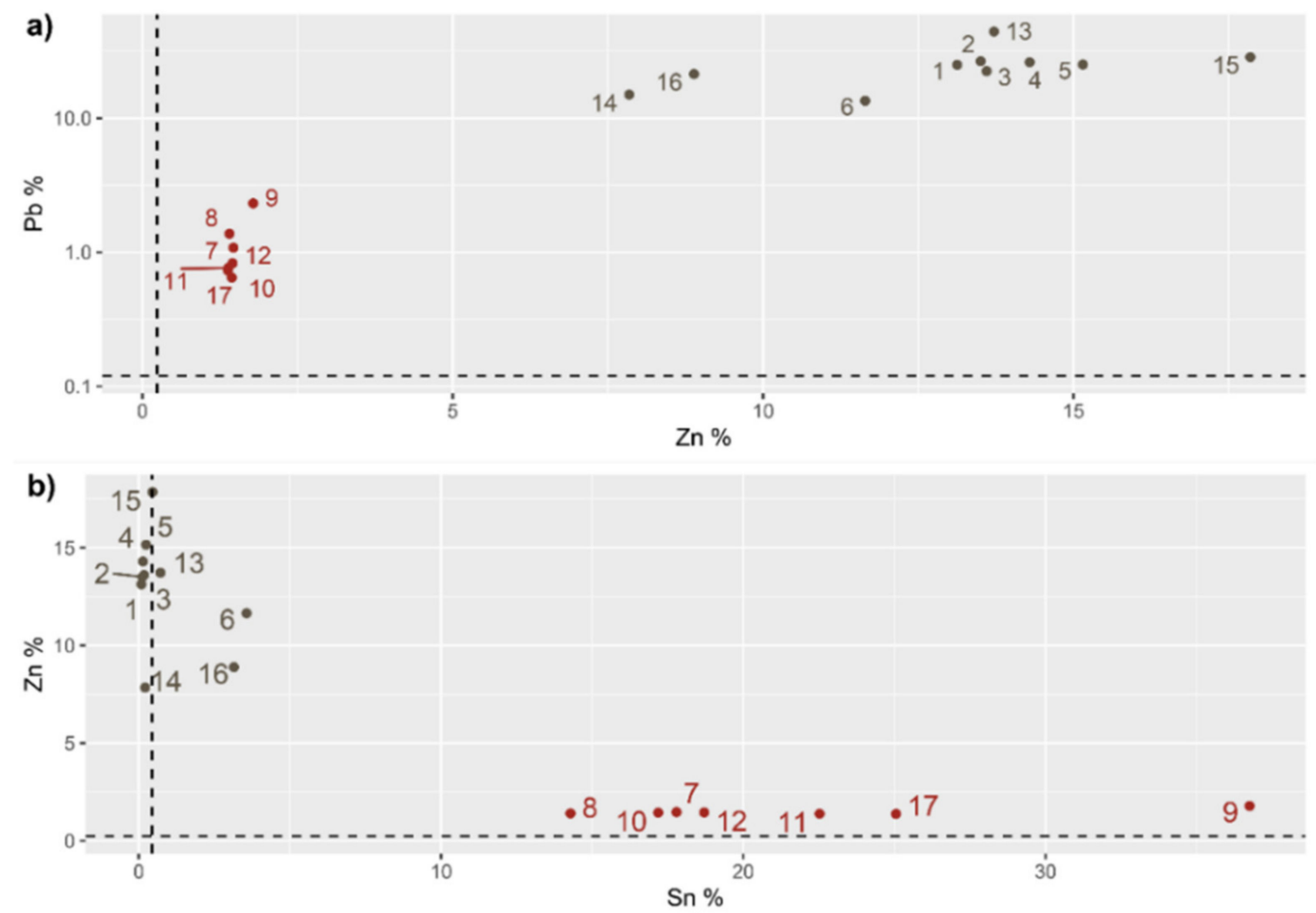

c)
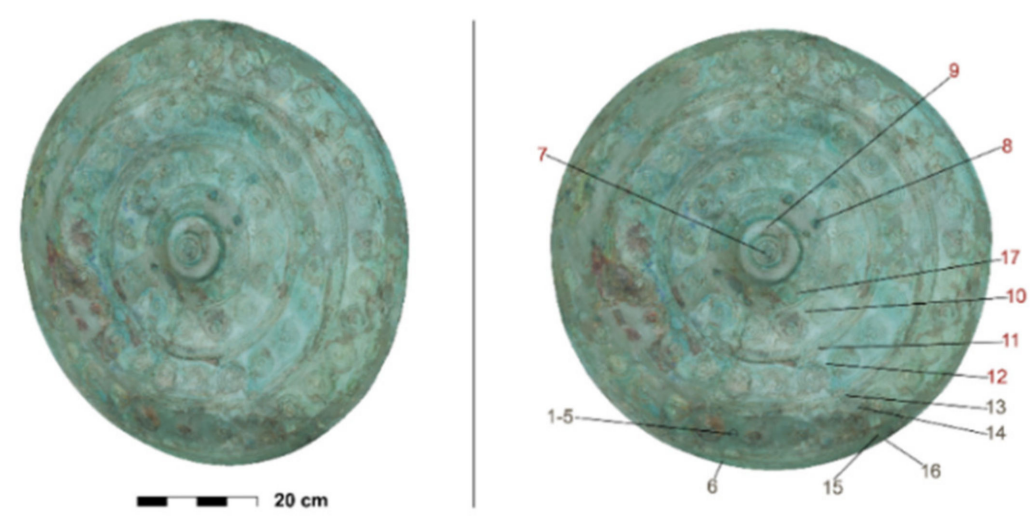

Figure 4. (a) Scatter plot of $\mathrm{Pb}$ and $\mathrm{Zn}$, (b) scatter plot of $\mathrm{Zn}$ and $\mathrm{Sn}$, (c) Assay locations on VG013 (shield from Veii, Casale del Fosso, tomb 871). Grey represents assays on reconstructed material. Red represents assays represent assays on 'original' material. Dashed lines indicate the limits of detection. 


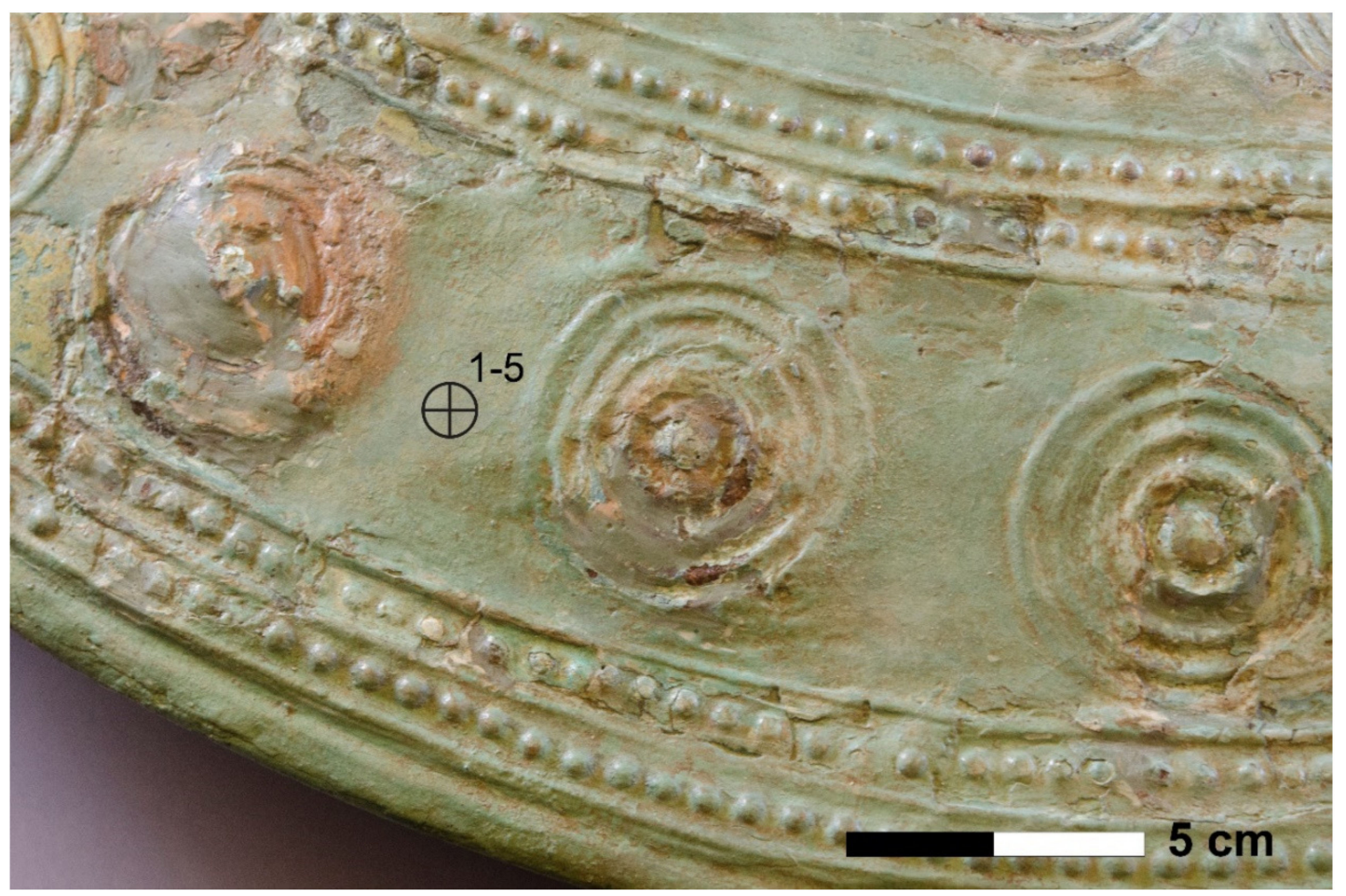

Figure 5. Detail photograph of the cluster assay location on VG013 (shield from Veii, Casale del Fosso, tomb 871).

Examination of the composition of all objects by century identified some trends (Figure 6). On average, the amount of Fe tends to decrease over time, with some outliers. The general trend towards less Fe and other trace elements in the objects may suggest the recycling of bronze, which allows for the gradual removal of unwanted elements with each iteration $[21,22,56]$, while the outliers may represent objects where new sources of bronze were introduced or where Fe was perhaps even purposely added. Arsenic generally decreases over time as well, as does $\mathrm{Sn}$ and $\mathrm{Pb}$. Additionally, the range within which these elements appear also seems to shrink, suggesting less variability in (and perhaps more control over) the alloy over time. Mn and $\mathrm{Zn}$ remain largely stable over time, with one outlier from the eighth century BCE, which is the shield VG013 commented on above. However, as $\mathrm{Mn}$ in particular could not be reduced to the metallic state with ancient smelting technologies (modern techniques require a blast or electric furnace), this likely relates to corrosion. There is also some variation in As and Sn in objects from the fourth century which is related to their geographic distribution.

When the averaged elements are viewed by the type of object, patterns are also observed (Figure 7). In general, objects which have more embellishment, and which seem to represent more decorative pieces (including belts and shields), tend to have less consistency within the elements measured. This suggests a range of manufacturing processes were practiced and that different elements may have been added to achieve different visual impacts. It is possible that this is also reflected in the relatively variable, and often high, levels of As present in those objects, as As could be used to create a more ductile medium for manipulation which was more conducive for producing thin sheets [57]. This suggestion is complicated by the fact that it is uncertain whether As had actually been identified as a discrete element/metal during this period, although the qualities of high-As bronze, whether produced deliberately or accidentally, were certainly known [58]. 

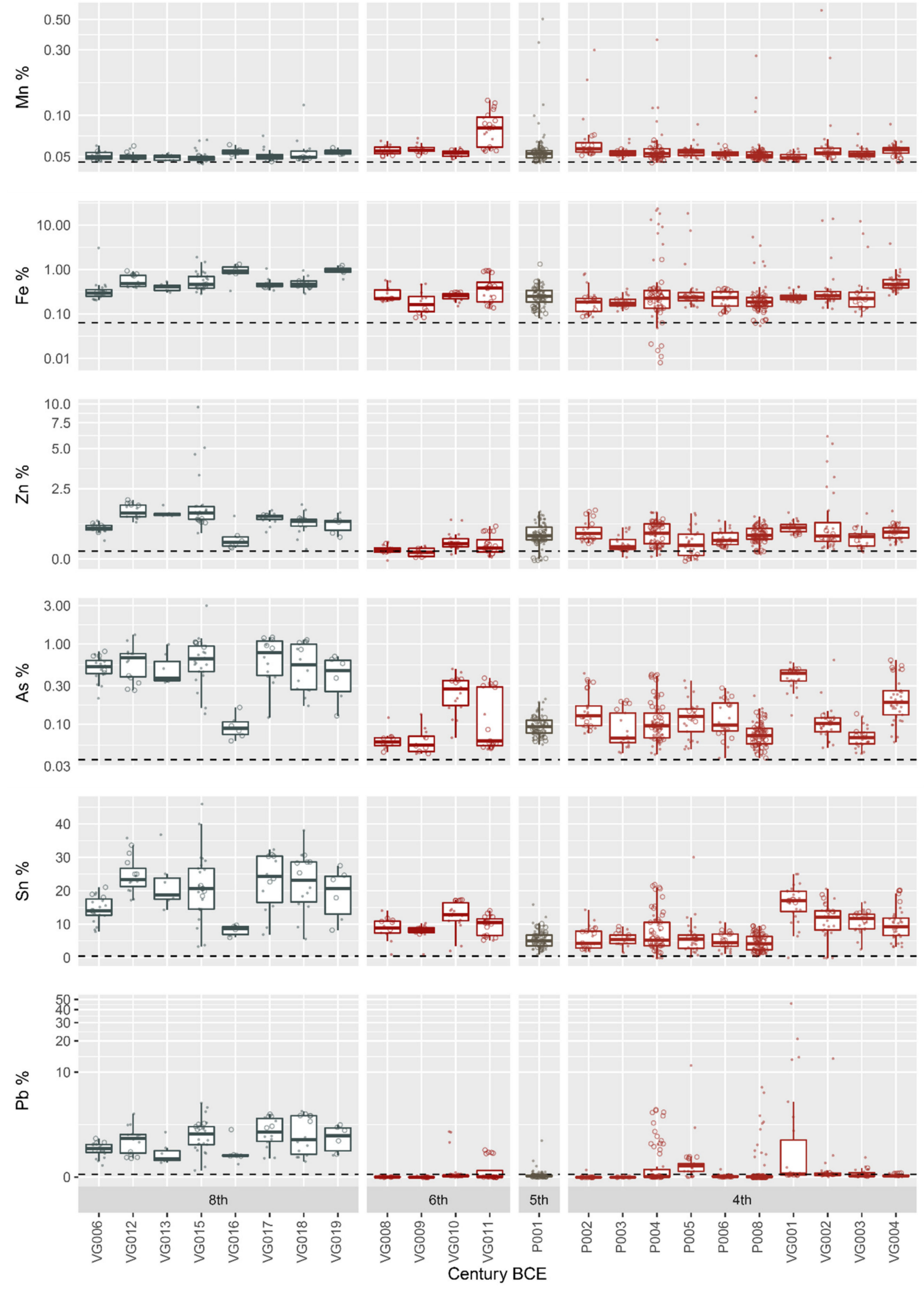

Figure 6. Box-plots of elements organised by century BCE. $\bigcirc$ denotes assay used in cluster assays. • denotes non-cluster assay. Dashed lines indicate the limits of detection. 


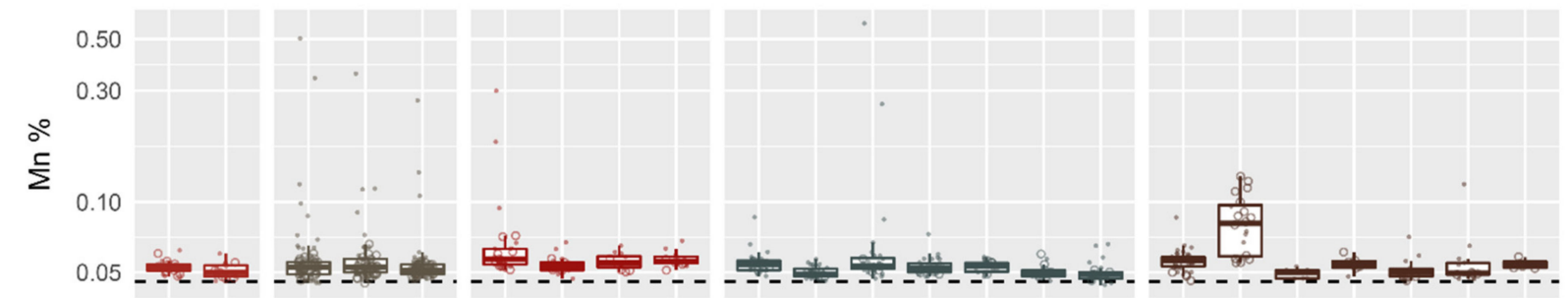

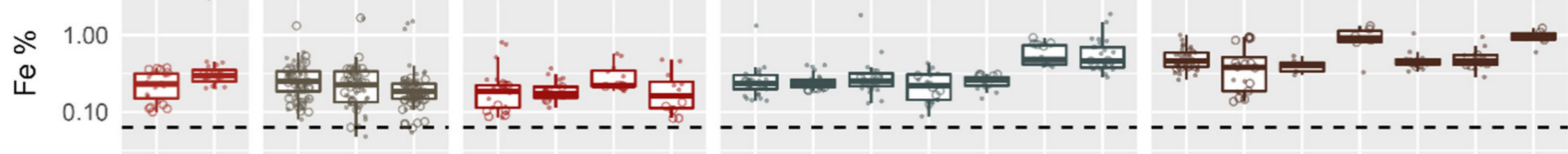
0.01
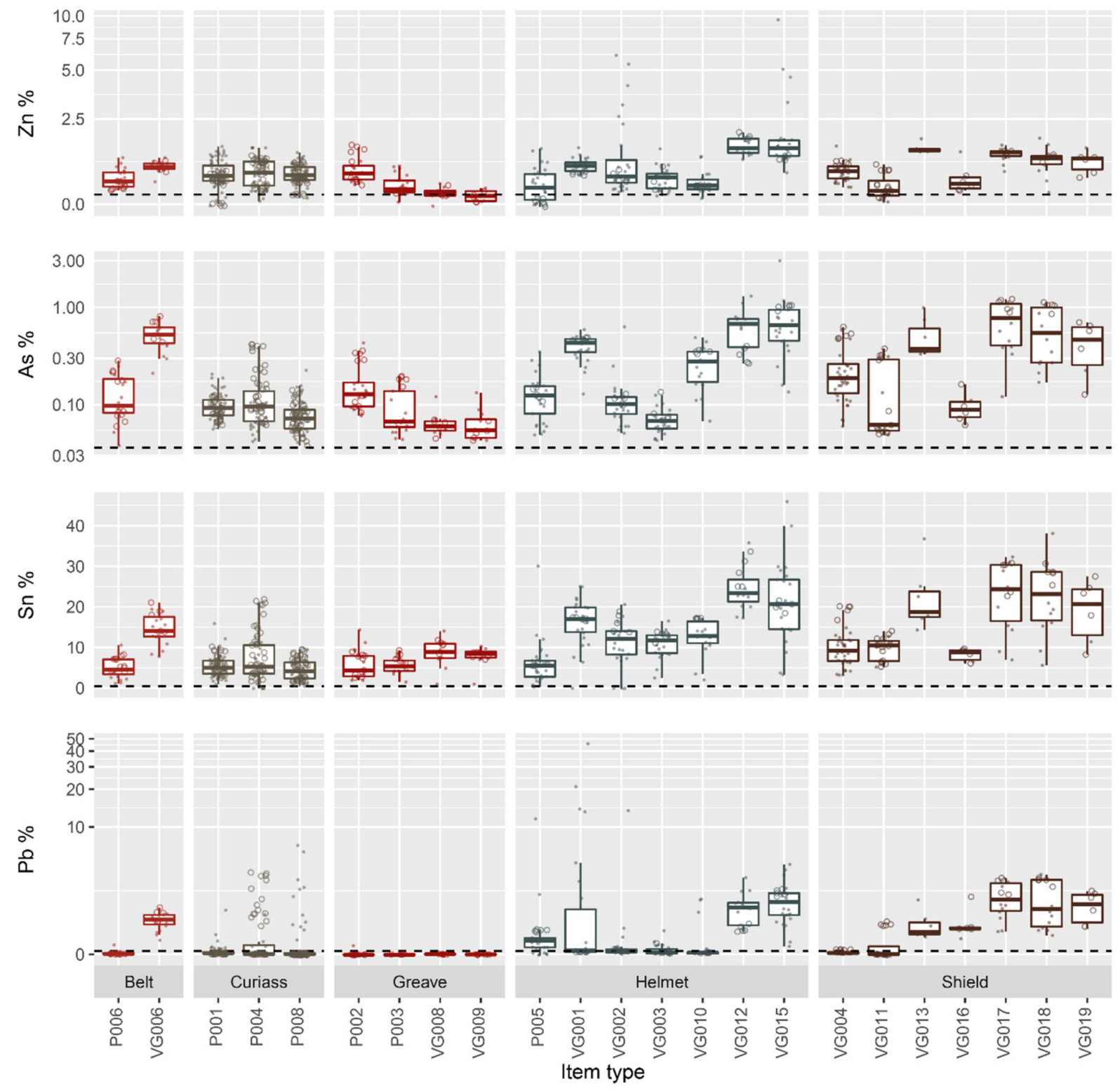

Figure 7. Box-plots of elements organised by type. $\bigcirc$ denotes assay used in cluster assays. - denotes non-cluster assay. Dashed lines indicate the limits of detection. 
It is possible that As was added, along with elements like antimony $(\mathrm{Sb})$ and nickel (Ni), through the addition of fahlore, or fahlerz ores or the recycling of high-As items. Conversely, items like greaves, which seem to have seen little innovation or variation in either form or production techniques across the period in question, remained remarkably consistent and stable in terms of the chemical composition of the alloy used.

\section{Discussion}

Both single pXRF assays and cluster assays seem to have merit and value independently. However, they can be best deployed in tandem. Clustered assays provide a base characterisation for the item by which other single assays can be validated. Single assays seem to give an accurate reading of the material at the specific point which is measured, but given variability across items, caused by both the natural heterogeneity of the bronze and variations in corrosion and patina, it can be difficult to use any single measurement as a standard reading. The above being noted, results from the analysis reveal that pXRF on ancient bronze can currently, at best, be used to make relative comparisons. This is particularly true if the item is heavily patinated. Indeed, even within a relative context and on relatively 'clean' pieces, levels of $\mathrm{Cu}$ vary significantly, suggesting they should not be seen as consistently reliable. However, certain other elements (Mn, Zn, As, Sn, Pb, and we would suggest $\mathrm{Fe}$ ), offer more stable readings and, again taken relatively, can be understood to function with minimal variability across a single piece of bronze.

Fe has, to date, represented something of a problem for bronze analyses, and is usually seen as either an impurity if found in the alloy (given the typically negative characteristics it brings to bronze) or a part of the patina derived from the soil [10]. Fe (like Mn and $\mathrm{Ni}$, as lighter elements with lower x-ray energy) is only detectable to a depth of between $0.05-0.1 \mathrm{~mm}$ in bronze matrices and their associated patinas (e.g., cuprite, atacamite), compared to $0.2-0.4 \mathrm{~mm}$ for heavier elements like $\mathrm{Cu}$ and $\mathrm{Zn}$. When these lighter metals are detected, particularly on heavily corroded pieces, it is more likely that they come from the patina. Our work has suggested that Fe may sometimes be included in the more stable readings typically associated with the alloy, although this must be done carefully. Destructive analyses have indicated that Fe does often appear in higher quantities in the upper layers of patinas on many bronze objects, suggesting it may originate in the soil and not the alloy in some contexts [59]. However, in our samples, Fe variations followed patterns similar to other alloy-based elements with a general decrease over time and no significant variation due to location. In later periods (c. $400 \mathrm{BCE}$ ), there appear to be shifts in the use of Fe in ancient bronze in Italy, which is detectable via pXRF on both cleaned and patinated pieces (this is explored further in a forthcoming publication). Although not conclusive, it is suggestive that we should perhaps pay more attention to temporal variability in Fe in future studies.

In addition to $\mathrm{Fe}$, our study indicates decreasing concentrations of $\mathrm{As}, \mathrm{Pb}$, and $\mathrm{Sn}$ over time (Figure 6). In particular, the eighth century BCE pieces possess both higher concentrations and increased variability of these elements, which may suggest a lower degree of standardization at that time. Sn varies slightly more than other elements (apart from $\mathrm{Cu}$ ), likely due to making up a slightly higher percentage of the initial core metal and its tendency to appear in higher quantities in many patinas [60]. It is also worth noting that some types of armour seem to have distinctive chemical signatures, no matter where they are from or their period, likely by virtue of their means of construction and function. For instance, greaves were shown to consistently have low levels of $\mathrm{Pb}$. This is likely a result of both their creation through extensive hammering and the need for them to maintain a degree of spring tension to be equipped.

Accordingly, it is also important to understand the depositional environment in which objects were found. For instance, an oxygenated corrosive environment adjusts the distribution of some elements [37]. This is an area where changes in conservation practice could help with future work, as an analysis of the soil removed from excavated bronzes during the initial cleaning of an artefact and from various sections of the excavated bronze 
would be useful in understanding the patination process and how it may have impacted the readings. There is also some opacity about conservation practices, particularly in earlier periods of modern cultural heritage management, due to the different objectives of academic and heritage institutions [61]. Since the 1980s, conservation often includes being cleaned mechanically and being treated for bronze disease using benzotriazole, before any fragments are jointed together, gaps filled with plasticine vel sim and modelling paste, and then being painted [62]. However, practices vary over time and location, as do the compounds used, and all known methods would involve leaving some residue or material on the surface which would be detected by the pXRF.

Repairs and interventions on ancient items are relatively easy to identify when analyzed with pXRF. This is evident in the analysis of shield VG013 discussed above. This shield is certainly ancient, with a secure archaeological provenance (excavated in the early 20 th century $[48,50,63])$, but was heavily reconstructed and restored multiple times postexcavation (Figure 8). The cluster reading taken was initially thought to be on an ancient part of the shield, although closer analysis of the results combined with detailed visual analysis of the macrophotography and previous photographs and line drawings, revealed it to be a partially restored section. The pXRF readings, however, were not wholly out of line from what one might expect from a decorative piece of ancient bronze, which seems to underlie the repair-i.e., this location contained a layer of restoration over an ancient core. This is visible in the lower levels of $\mathrm{Cu}$ and $\mathrm{Sn}$ measured in these sections, compared to other sections where the original material was exposed (e.g., assays 7-12 and 17), coupled with higher levels of $\mathrm{Zn}$ and $\mathrm{Pb}$. While all of these elements are often impacted by the patination processes, the ratios here are abnormal. With a normal piece of patinated bronze, and indeed on other sections of this shield, both $\mathrm{Pb}$ and $\mathrm{Sn}$ are typically enhanced, while $\mathrm{Zn}$ is depleted [55].

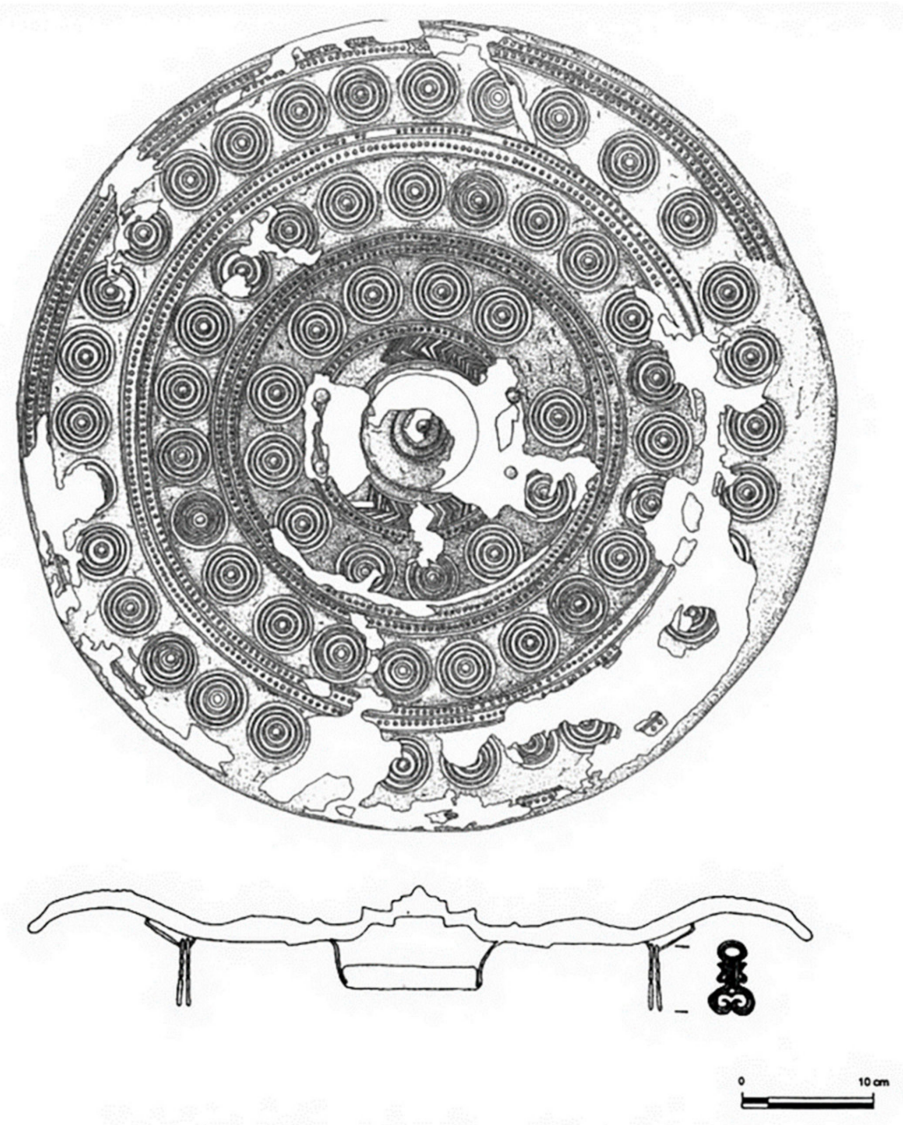

Figure 8. Example of the early reconstruction on VG013, after Drago Troccoli [64] (p. 102). 
The lower $\mathrm{Sn}$, but higher $\mathrm{Pb}$ and $\mathrm{Zn}$, seen in these readings on VG013 may therefore relate to the compound used to reconstruct the artefact, an interpretation also supported by the lower $\mathrm{Cu}$ which may be a result of an extra material on top of the bronze. Cluster assays using pXRF, and particularly when done across the totality of an artefact, are therefore most beneficial for identifying repairs, but although perhaps not outright forgery. Again, they are best used for relative readings within a single piece. The technique could be usefully combined with radiography, which has long been deployed to detect reconstructed section of artefacts [65], as a quicker technique which can occur 'on site'.

Although it is difficult to compare readings outside of a single piece, due to the variability noted above, some basic trends were also visible. For instance, given the significant differences visible in the readings from items from individual contexts, and even from different components of a single piece, our work supports the suggestion that ancient craftspeople were using particular alloys for particular items, and even for particular aspects of a single, composite item [66]. The use of specific bronze alloys for specific items is attested in Italy going back to the Eneolithic [67], while bronze alloys seem to standardise during the Bronze Age, there is evidence that they began to diversify again in the Iron Age [68]. There is also evidence for, again stretching back to the Bronze Age, using different alloys for helmet caps and knobs. As Mödlinger noted ([69], p. 188), referring to helmets from the European Bronze Age: "Whereas all caps show an alloy composition with tin ranging from 7 to $12 \mathrm{wt} . \%$, the smaller components of the helmets (such as the knobs) were cast from much more heterogeneous tin alloys." It is likely that these differences related to production practices, with the higher tin content of the caps explained by the desire to create a thinner, harder, and stronger sheets.

In the items analysed in this study, the most obvious examples of the use of specific alloys and materials for specific purposes is the use of rivets. In later items these are often made of $\mathrm{Fe}$, although in earlier pieces they are made from different types of bronze alloys. Many decorations, which appear to have been cast and then soldered on (as solder is often still visible around the base of items and in places where pieces have broken off - as on the Samno-Attic Helmet (P005)), are also composed of a different alloy. For instance, the earpieces on VG001 contain a significantly higher percentage of lead $(\mathrm{Pb})$, presumably in order to lower the melting temperature, increase fluidity, and make casting easier. The same is true for the decorative attachments to VG010. One can also clearly identify locations where pieces were soldered on, typically using $\mathrm{Sn}$.

Our work confirms the current communis opinio, that accurate pXRF measurements of the original or core metal (if it still exists in its original form) are effectively impossible on patinated bronze. If one is attempting to get an accurate elemental signature of the core metal, destructive techniques must be employed. However, it is worth considering whether this is advisable in all cases. As noted above, even on a cleaned piece of bronze, patination processes (esp. intercrystalline corrosion) can change the elemental composition of what might appear to be the core metal, meaning that not only will the resultant readings be variable, but they will not reflect the original material. This is particularly problematic with items produced from thin sheets, like the armour examined in this study, where a thick core of untouched alloy is not available. Additionally, as demonstrated by the range visible in the readings taken across a single (even cleaned) artefact, the inherent variability of ancient bronze means that an 'accurate' reading, taken using destructive techniques, may not be indicative of the overall composition of an item rather that of the specific point analysed. The patina certainly causes significant issues in interpretation and the level of uncertainty it introduces is greater than that which comes with destructive testing, but not by orders of magnitude.

We suggest that non-destructive, surface-based, elemental analysis (pXRF) is a viable technique for analysing ancient bronzes particularly where destructive analyses are not possible. Complimentary information from methods such as radiography, multimodal images, and the trained eye of a conservator are also useful. Both destructive and non-destructive, surface-based techniques return results which must be understood as approximate, given 
both the inherent variability within ancient bronze and the variable nature of mineralization and patination processes across an artefact. While the patina certainly increases the range and nature of this variability for non-destructive, surface-based techniques - particularly with regards to $\mathrm{Cu}$ and $\mathrm{Sn}$-we would suggest that the benefits do not outweigh the myriad issues involved in damaging or destroying an artefact. Additionally, when working with ancient items made from thin bronze sheets, there is little to be gained from destructive testing as there is often no core metal left to test due to cuprification. This being noted, the issues involved in surface-based techniques must be accounted for. First, we would recommend taking a series of assays across each individual piece of bronze analysed. A single assay will not allow the comparison required to understand the relatively variability. These assays should include areas of low patina if possible. They should also include areas where the patina is visually different. If practical, multiple readings (in a grid or cruciform pattern) should be taken of each area (Figure 2). The goal is to gain as comprehensive an understanding of the elemental signature of the surface across the entire piece as possible. This set of readings can then be compared and contrasted. In the analysis, reading for $\mathrm{Cu}$ should be largely discounted and patination processes always considered when looking at trace elements. However, initial results suggest that some relative measurements may be achievable, both within a single piece and assemblage, and across multiple pieces and assemblages.

\section{Conclusions}

The elemental characterization of ancient bronze, although problematic, still offers potential benefits for scholars. When exploring issues of provenance, production, or use, the evidence pXRF offers does add to the dataset of these items. In particular, its ability to give an indication of trace elements within ancient bronze can add to our understanding of how specific alloys were deployed in particular contexts and periods. For instance, in the items analysed in this study there is a decrease in Sn and Fe concentrations over time, possibly due to recycling and purification of the alloy over time. The results also suggest the use of specific materials and different bronze alloys for different items and aspects of ancient military equipment, particularly shields and helmets. It is evident that for ancient smiths, all bronze was not the same. While they might not have been able to achieve the same levels of homogeneity and exactness in their mixtures and recipes which are available today, pXRF data suggests that they were consciously manipulating their alloys to achieve specific results with specific aspects of the equipment and that these aims and methods changed over time. Clearly more work needs to be done on this, but we are confident that, if the techniques are appropriately deployed and the results appropriately interpreted, there is much more we can learn.

Supplementary Materials: The following are available online at https:/ /www.mdpi.com/article/10 .3390/min11070697/s1, Figure S1: Assay Locations, Table S1: Assay data.

Author Contributions: Conceptualization, J.E. and J.A.; Methodology, J.E., A.M. and J.A.; Validation, J.E., A.M. and J.A.; Formal Analysis, J.E., A.M.; Investigation, J.E. and A.M.; Resources, J.E. and J.A.; Data Curation, J.E. and A.M.; Writing-Original Draft Preparation, J.E., A.M., J.A.; Writing-Review \& Editing, J.E., A.M. and J.A.; Visualization, J.E., A.M.; Supervision, J.A.; Project Administration, J.A.; Funding Acquisition, J.A. All authors have read and agreed to the published version of the manuscript.

Funding: This work was supported by the Royal Society of New Zealand Marsden Fund project "Blood and Money: The 'Military Industrial Complex' of Archaic Central Italy" [17-UOA-136].

Data Availability Statement: The calibrated assays used in this study along with their locations on the objects and calibration procedures are available as Supplementary Materials to this paper.

Acknowledgments: The authors wish to thank the directors and curators from the Teece Museum, Museo Nazionale Etrusco di Villa Giulia and Museo Archeologico Nazionale di Paestum for facilitating access to their collections and allocating staff, space, and time to help us during our visit, and for granting us permission to publish the data. In particular we would like to thank Giulia Bison and 
Gabriel Zuchtriegel for their help. We are very grateful for the feedback provided on a draft of this article by Marianne Mödlinger-all errors and omissions remain our own. Finally, thanks is also due to Tim Mackrell helped to facilitate transport of the equipment from Auckland to Italy and back.

Conflicts of Interest: The authors declare no conflict of interest.

\section{Appendix A. Portable X-ray Fluorescence Calibration Procedures}

One approach for ancient bronze studies has been to use the in-built factory calibrations supplied with some instruments (e.g., [25,70]). These types of calibrations are, however, generally intended for the rapid identification of modern bronze and brass alloys and, as such, are not necessarily optimised for ancient alloys. For this reason, Heginbotham and colleagues [71] developed the CHARM set of reference materials especially for the analysis of heritage copper alloys. Unfortunately, the CHARM set is not currently in production, which necessitated the use of nine modern copper-based alloy reference standards instead (Table A1). Although these standards have a similar range of elemental concentrations as the CHARM set, the range of elements is more limited.

In this study we used a Bruker Tracer III-SD portable X-ray Fluorescence ( $p$ XRF) analyser. The instrument employs an x-ray tube with a Rh target and a $10 \mathrm{~mm}^{2}$ silicon drift detector (SDD) with a typical resolution of $145 \mathrm{eV}$ at 100,000 cps. For analysis of copperbased alloys, we found that operating the x-ray tube with a setting of $40 \mathrm{keV}$ at $5.0 \mu \mathrm{A}$ in an air-path and through a window composed of 12 mil Al and 1 mil Ti filters (Bruker's Yellow filter) provided a good count rate for the elements of interest. Assays of artefacts were taken for 60 seconds each, which was sufficient time for the count rates to stabilise, and is in line with other researchers using similar instruments [25,72,73]. Each reference standard was analysed twice and the results averaged. Assays of artefacts were taken using the same instrument and settings outlined above, and their locations were recorded on annotated photographs and transcribed to a photogrammetric model of each object.

Given the relatively small number of standards available, the calibration procedure was kept as simple as possible. Linear regressions on the net characteristic element peaks (normalised to counts-per-second) were employed, and corrections for interference peaks were included in the regression formulas where necessary (Table A2, Figure A1). For example, the escape $\mathrm{K} \alpha$ peak of $\mathrm{Cu}(6.306 \mathrm{keV})$ overlaps with the characteristic $\mathrm{K} \alpha$ peak of $\mathrm{Fe}(6.405 \mathrm{keV})$ and introduces error if not accounted for in the regression equation.

Table A1. Reference standards used for the calibration with given values (\%). Uncertified values are underlined. ${ }^{1}$ Outlier removed from calibration.

\begin{tabular}{|c|c|c|c|c|c|c|c|c|c|}
\hline & Mn & $\mathrm{Fe}$ & $\mathbf{N i}$ & $\mathrm{Cu}$ & $\mathrm{Zn}$ & As & Sn & $\mathrm{Sb}$ & $\mathrm{Pb}$ \\
\hline \multicolumn{10}{|c|}{ Given Values } \\
\hline BCR-691-A & $\underline{0.20}$ & $\underline{0.20}$ & $\underline{0.10}$ & $\underline{76.50}$ & 6.02 & 0.19 & 7.16 & 0.50 & 7.90 \\
\hline BCR-691-B & $\underline{0.40}$ & $\underline{0.50^{1}}$ & 0.20 & 81.00 & 14.80 & 0.10 & 2.06 & - & 0.39 \\
\hline BCR-691-C & $\overline{0.20}$ & $\overline{0.20}$ & - & $\overline{95.00}$ & 0.06 & 4.60 & 0.20 & 0.50 & 0.18 \\
\hline BCR-691-D & $\underline{0.10}$ & $\underline{0.10}$ & $\underline{0.30}$ & $\underline{80.50}$ & 0.15 & 0.29 & 10.10 & 0.30 & $9.20^{1}$ \\
\hline BCR-691-E & $\underline{0.30}$ & $\underline{0.30}$ & $\underline{0.50}$ & 91.50 & 0.16 & 0.19 & 7.00 & 0.70 & 0.20 \\
\hline МBH-32Х PB11 & 0.04 & 0.37 & 0.72 & 92.09 & 1.60 & 0.19 & 3.20 & 0.47 & 1.08 \\
\hline MBH-32X SN6B & 0.09 & 0.38 & 0.30 & 85.73 & 2.00 & 0.80 & 6.78 & 0.30 & 1.64 \\
\hline МBH-33X 54400A & - & 0.07 & 0.24 & 86.79 & 3.87 & 0.02 & 3.97 & 0.04 & 4.69 \\
\hline MBH-33X RB2 B & 0.08 & 0.50 & 0.33 & 82.02 & 9.01 & 0.04 & 4.65 & 0.05 & 2.99 \\
\hline \multicolumn{10}{|c|}{ Calibrated Values } \\
\hline BCR-691-A & 0.17 & 0.21 & 0.07 & 78.21 & 5.72 & 0.19 & 6.72 & 0.46 & 8.00 \\
\hline BCR-691-B & 0.42 & - & 0.25 & 85.34 & 15.10 & 0.11 & 2.04 & - & 0.43 \\
\hline BCR-691-C & 0.21 & 0.20 & - & 96.21 & -0.01 & 4.62 & 0.10 & 0.54 & 0.25 \\
\hline BCR-691-D & 0.10 & 0.11 & 0.29 & 79.50 & 0.46 & 0.30 & 9.79 & 0.27 & - \\
\hline BCR-691-E & 0.27 & 0.32 & 0.48 & 86.63 & 0.31 & 0.19 & 7.40 & 0.68 & 0.22 \\
\hline МBH-32Х PB11 & 0.09 & 0.37 & 0.71 & 91.33 & 1.56 & 0.19 & 3.22 & 0.49 & 1.06 \\
\hline MBH-32X SN6B & 0.11 & 0.34 & 0.34 & 83.00 & 2.00 & 0.72 & 7.14 & 0.34 & 1.75 \\
\hline МBH-33X 54400A & - & 0.09 & 0.22 & 86.89 & 3.86 & 0.07 & 3.97 & 0.04 & 4.59 \\
\hline MBH-33X RB2 B & 0.06 & 0.52 & 0.35 & 84.04 & 8.68 & 0.07 & 4.77 & 0.05 & 2.80 \\
\hline
\end{tabular}


Table A2. Calibration parameters. ${ }^{1}$ Detection limit calculated as $3.3 \times(\sigma / S)$.

\begin{tabular}{|c|c|c|c|c|c|c|c|}
\hline \multirow{2}{*}{ Element } & Conc. & $\mathbf{R}^{2}$ & RMS & Mean Abs. & Det. & Element & Interference \\
\hline & Range (\%) & & Error (\%) & Error (\%) & Lim. ${ }^{1}$ & Peak & Corrections \\
\hline Mn & $0.04-0.40$ & 0.944 & 0.03 & 0.02 & 0.05 & $\mathrm{Mn} \mathrm{K} \alpha 1$ & - \\
\hline $\mathrm{Fe}$ & $0.07-0.50$ & 0.989 & 0.02 & 0.01 & 0.06 & Fe K $\alpha 1$ & $\mathrm{Cu} \mathrm{K} \alpha 1$ (Escape peak) \\
\hline $\mathbf{N i}$ & $0.10-0.72$ & 0.976 & 0.03 & 0.03 & 0.05 & $\mathrm{Ni} K \alpha 1$ & $\mathrm{Cu} \mathrm{K} \alpha 1$ (Peak overlap) \\
\hline $\mathrm{Cu}$ & $76.50-95.00$ & 0.806 & 2.59 & 2.08 & 34.84 & $\mathrm{Cu} \mathrm{K} \alpha 1$ & - \\
\hline $\mathrm{Zn}$ & $0.06-14.80$ & 0.998 & 0.21 & 0.17 & 0.24 & $\mathrm{Zn} \mathrm{K} \alpha 1$ & Cu K $\beta 1$ (Peak overlap) \\
\hline As & $0.02-4.60$ & 0.999 & 0.04 & 0.02 & 0.04 & As $K \beta 1$ & - \\
\hline Sn & $0.20-10.10$ & 0.992 & 0.26 & 0.20 & 0.44 & Sn $K \alpha 1$ & - \\
\hline $\mathrm{Sb}$ & $0.01-0.70$ & 0.987 & 0.03 & 0.02 & 0.06 & $\mathrm{Sb} \mathrm{K} \alpha 1$ & - \\
\hline $\mathrm{Pb}$ & $0.18-7.90$ & 0.999 & 0.10 & 0.08 & 0.12 & $\mathrm{~Pb} \mathrm{~L} \beta 1$ & - \\
\hline
\end{tabular}
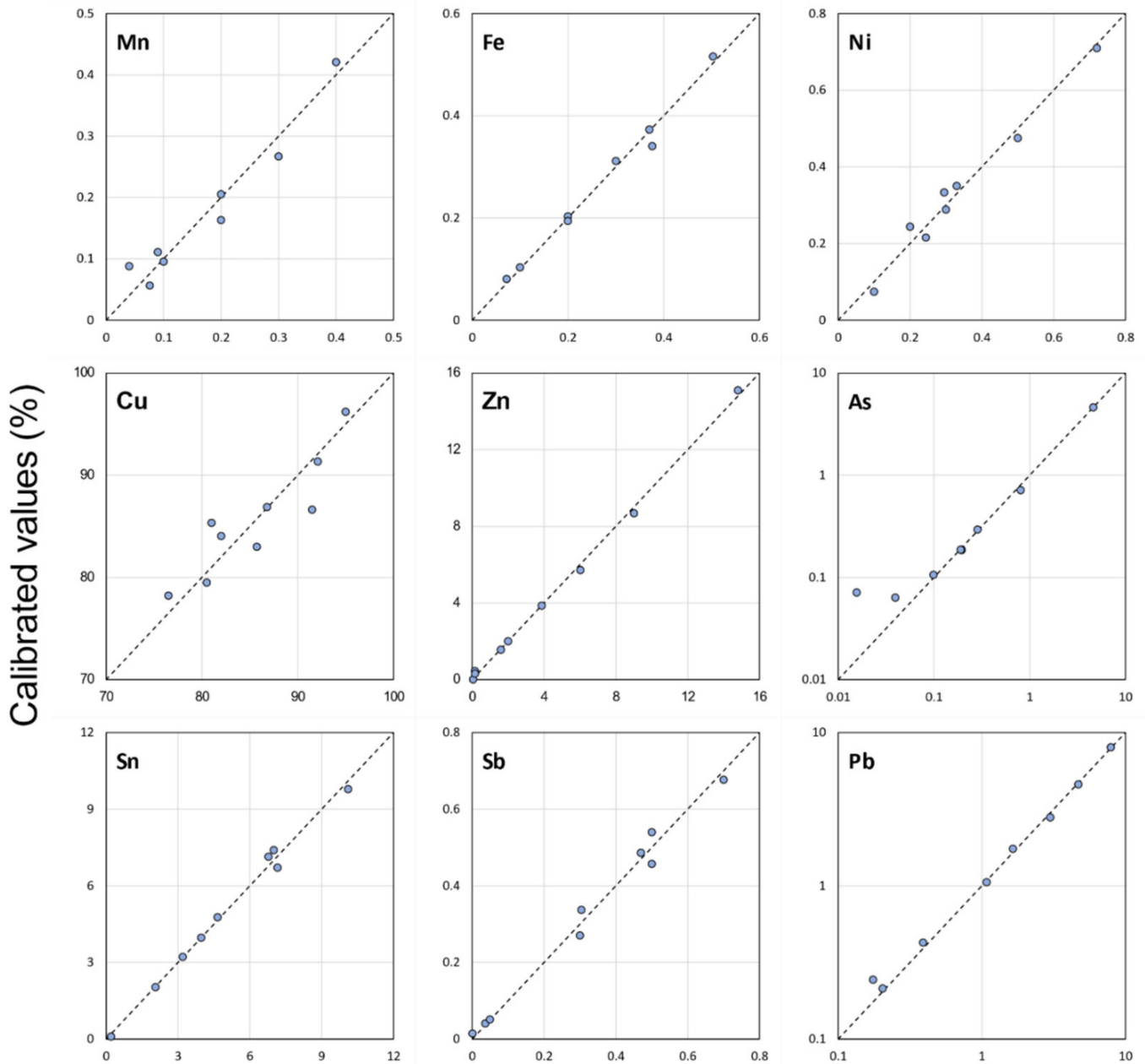

\section{Given values (\%)}

Figure A1. Scatterplots of given versus calibrated values for the reference standards. The dashed black lines show the ideal 1:1 $x$-y line. As and $\mathrm{Pb}$ are shown with logarithmic axes.

In the case of three elements $(\mathrm{Ni}, \mathrm{Sb}$ and $\mathrm{Pb})$ slightly negative values were occasionally obtained from the calibration. Examination of typical spectra indicates that, at low concentrations, the peaks for these elements are swamped by the tails of the much larger $\mathrm{Cu} \mathrm{K} \alpha$ and $\mathrm{K} \beta$ peaks at low concentrations (Figure A2). 


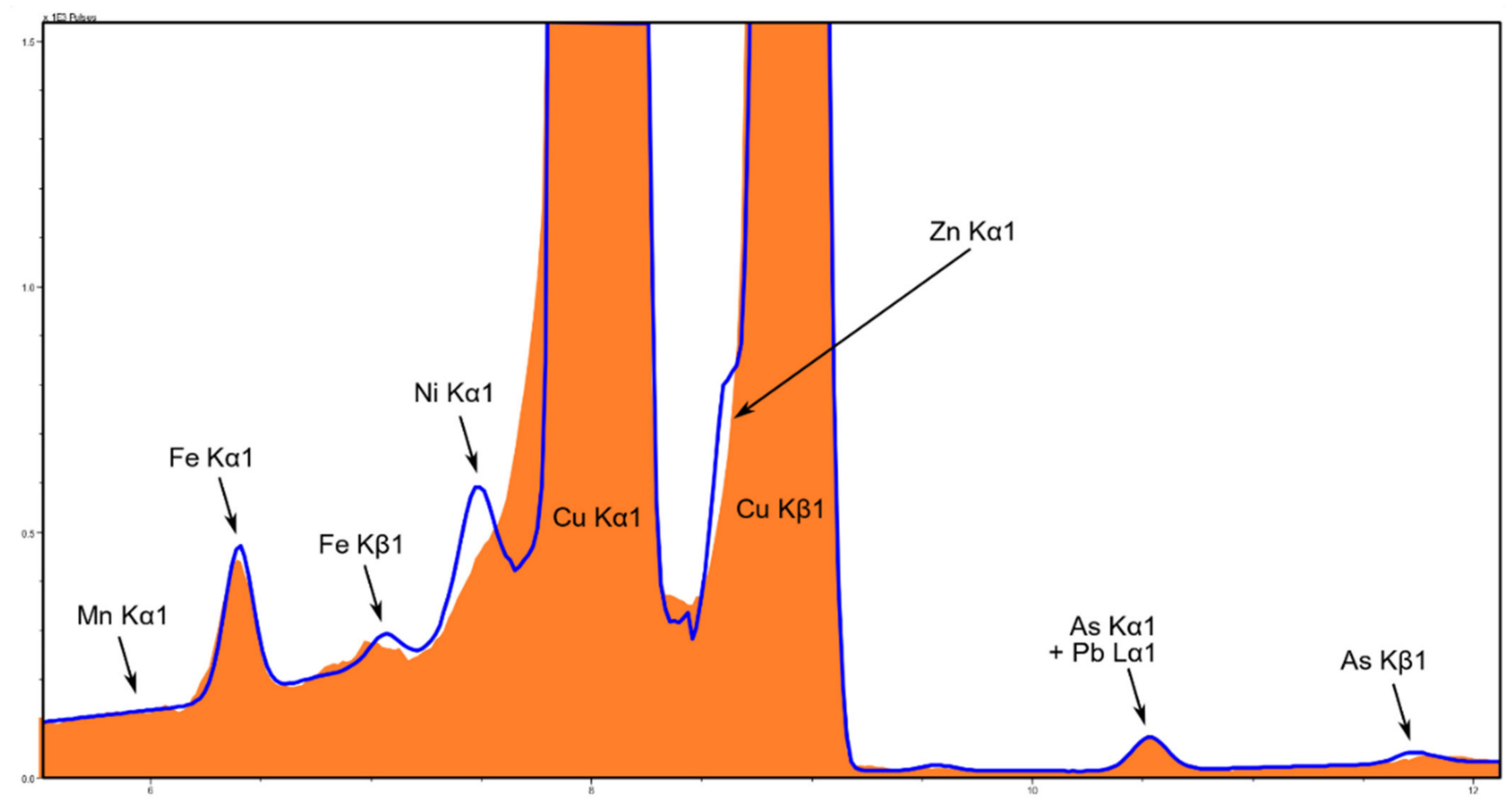

Figure A2. Spectrum of a typical bronze piece, showing the $\mathrm{Cu} \mathrm{K} \alpha$ peak overlap on $\mathrm{Ni}$ and the $\mathrm{Cu} \mathrm{K} \beta$ overlap Zn. The spectrum is shown in orange and the fitted peaks (using Bruker's Artax v.8.0 software) as a blue line.

\section{References}

1. Burns, M. The Cultural and Military Significance of the South Italic Warrior's Panoply from the 5th to the 3rd Centuries BC; University College London: London, UK, 2005.

2. Kagan, D.; Viggiano, G.E. (Eds.) Men of Bronze: Hoplite Warfare in Ancient Greece; Princeton University Press: Princeton, NJ, USA, 2017.

3. Egg, M. Studien zu den Ältereisenzeitlichen Helmen Italiens und der Alpen; Verlag des Römisch-Germanischen Zentralmuseums: Mainz, Germany, 1986; Volume 1-2.

4. Bottini, A.; Egg, M.; von Hase, F.; Pflug, H.; Schaff, U.; Schauer, P.; Waurick, G. Antike Helme. Sammlung Lipperheide und andere Bestände des Antikenmuseums Berlin mit Beiträgen; Verlag des Römisch-Germanisches Zentralmuseums: Mainz, Germany, 1988.

5. Paddock, J. The Bronze Italian Helmet: The Development of the Cassis from the Last Quarter of the Sixth Century B.C. to the Third Quarter of the First Century A.D. Ph.D. Thesis, University of London, London, UK, 1993.

6. Born, H. Antike Herstellungstechniken: Gegossene Brustpanzer und Helme aus Italien. Acta Praehist. Archaeol. 1989, $21,99-115$.

7. Born, H. Zur Herstellung der etruskischen Bronzehelme mit Scheitelknauf. Archäologisches Korresp. 1991, 21, 73-78.

8. Mattusch, C. Corinthian Bronze: Famous, but Elusive. In Corinth Volume 20, Corinth, the Centenary: 1896-1996; Williams, C.K., II, Bookidis, N., Eds.; The American School of Classical Studies at Athens: Princeton, NJ, USA, 2003; pp. $219-232$.

9. Riccucci, C.; Ingo, G.M.; Faustoferri, A.; Pierigè, M.I.; Parisi, E.I.; Di Carlo, G.; De Caro, T.; Faraldi, F. Micro-chemical and metallurgical study of Samnite bronze belts from ancient Abruzzo (central Italy, VIII-IV BC). Appl. Phys. A 2013, 113, 959-970. [CrossRef]

10. Mödlinger, M. Protecting the Body in War and Combat: Metal Body Armour in Bronze Age Europe; Austrian Academy of Sciences Press: Vienna, Austria, 2017.

11. Robbiola, L.; Mlengino, J.-M.; Fiaud, C. Morphology and mechanisms of formation of natural patinas on archaeological Cu-Sn alloys. Corros. Sci. 1998, 40, 2083-2111. [CrossRef]

12. Moreau, J.-F.; Hancock, R.G.V. L'anatomie d'un chaudron. In L'archéologie Sans la Loupe. Contributions à l'Archéométri; Moreau, J.-F., Ed.; Recherches Amérindiennes au Québec: Montréal, QC, Canada, 1999; Volume Paléo-Québec 29, pp. 73-86.

13. Scott, D. An Examination of the Patina and Corrosion Morphology of Some Roman Bronzes. J. Am. Inst. Conserv. 1994, 33, 1-23. [CrossRef]

14. Manti, P. Shiny Helmets: Investigation of Tinning, Manufacture and Corrosion of Greek Helmets (7th-5th c. BC). Ph.D. Thesis, Cardiff University, Cardiff, UK, 2012.

15. Nicholas, M.; Manti, P. Testing the applicability of handheld portable XRF to the characterisation of archaeological copper alloys. In Proceedings of the ICOM-CC 17th Triennial Conference Preprints, Melbourne, VIC, Australia, 15-19 September 2014; Bridgland, J., Ed.; International Council of Museums: Paris, France, 2014. 
16. Piccardo, P.; Mille, B.; Robbiola, L. Tin and copper oxides in corroded archaeological bronzes. In Corrosion of Metallic Heritage Artefacts-Investigation, Conservation and Prediction for Long-Term Behaviour; Dillmann, P., Beranger, G., Piccardo, P., Matthiesen, H., Eds.; Woodhead Publishing: Cambridge, UK, 2007; pp. 239-262.

17. Adriaens, A.; Dowsett, M. Electrochemical analysis of metallic heritage artefacts: Time-lapse spectroelectrochemical techniques. In Corrosion and Conservation of Cultural Heritage Metallic Artefacts; Dillmann, P., Watkinson, D., Angelini, E.A.A., Eds.; Woodhead Publishing: Cambridge, UK, 2013; pp. 149-164.

18. Dolfini, A.; Crellin, R.; Horn, C.; Uckelmann, M. Interdisciplinary Approaches to Prehistoric Warfare and Violence: Past, Present, and Future. In Prehistoric Warfare and Violence: Quantitative and Qualitative Approaches; Dolfini, A., Crellin, R., Horn, C., Uckelmann, M., Eds.; Springer: Cham, Switzerland, 2018; pp. 1-20. [CrossRef]

19. Pernicka, E. Trace element fingerprinting of Ancient Copper: A Guide to Technology or Provenance? In Metals in Antiquity; Young, S.M.M., Pollard, A.M., Budd, P., Ixer, R.A., Eds.; B.A.R.: Oxford, UK, 1999; pp. 163-171.

20. Pernicka, E. Provenance Determination of Archaeological Metal Objects. In Archaeometallurgy in Global Perspective; Roberts, B., Thornton, C., Eds.; Springer: New York, NY, USA, 2014; pp. 239-268. [CrossRef]

21. Merkel, J. Experimental reconstruction of Bronze Age copper smelting based on archaeological evidence from Timna. In The Ancient Metallurgy of Copper; Rothenberg, B., Ed.; Institute of Archaeo-Metallurgical Studies: London, UK, 1990.

22. Merkel, J. Summary of experimental results for Late Bronze Age copper smelting and refining. Mus. Appl. Sci. Cent. J. 1983, 2, 173-179.

23. Holmqvist, E.; Wessman, A.; Mänttäri, I.; Lahaye, Y. Lead isotope and geochemical analyses of copper-based metal artefacts from the Iron Age water burial in Levänluhta, Western Finland. J. Archaeol. Sci. Rep. 2019, 26, 101854. [CrossRef]

24. Iaia, C. Handicrafts, 10th cent.-730 BCE. In Etruscology; Naso, A., Ed.; DeGruyter: Berlin, Germany, 2017 ; pp. 739-758.

25. Charalambous, A.; Kassianidou, V.; Papassavas, G. A compositional study of Cypriot bronzes dating to the Early Iron Age using portable X-ray fluorescence spectrometry (pXRF). J. Archaeol. Sci. 2014, 46, 205-216. [CrossRef]

26. Letardi, P. Laboratory and field tests on patinas and protective coating systems for outdoor bronze monument. In Metal 04 , Proceedings of the International Conference on Metals Conservation, Canberra Australia, 4-8 October 2004; Ashton, J., Hallam, D., Eds.; National Museum of Australia: Canberra, Australia, 2004; pp. 379-387.

27. Hughes, R. Artificial patination. In Metal Plating and Patination: Cultural, Technical and Historical Developments; Niece, S., Craddock, P., Eds.; Butterworth-Heinemann: Oxford, UK, 2013; pp. 1-18.

28. Orfanou, V.; Rehren, T. A (Not So) Dangerous Method: Pxrf Vs. Epma-Wds Analyses of Copper-Based Artefacts. Archaeol. Anthropol. Sci. 2015, 7. [CrossRef]

29. Tykot, R.H. Investigating Ancient Bronzes: Non-Destructive Analysis of Copper-Based Alloys. In Artistry in Bronze: The Greeks and Their Legacy. Xixth International Congress on Ancient Bronzes; Daehner, J.M., Lapatin, K., Spinelli, A., Eds.; The J. Paul Getty Museum and the Getty Conservation Institute: Los Angeles, CA, USA, 2017; pp. 289-299.

30. Pearce, M. The Curse of the pXRF: The Negative Consequences of the Popularity of Handheld XRF Analysis of Copper-Based Metal Artefacts. Metalla 2019, 24, 81-85.

31. Speakman, R.J.; Shackley, M.S. Silo science and portable XRF in archaeology: A response to Frahm. J. Archaeol. Sci. 2013, 40, 1435-1443. [CrossRef]

32. Frahm, E. Is obsidian sourcing about geochemistry or archaeology? A reply to Speakman and Shackley. J. Archaeol. Sci. 2013, 40, 1444-1448. [CrossRef]

33. Šatović, D.; Desnica, V.; Fazinic, S. Use of Portable X-Ray Fluorescence Instrument for Bulk Alloy Analysis on Low Corroded Indoor Bronzes. Spectrochim. Acta Part B At. Spectrosc. 2013, 89, 7-13. [CrossRef]

34. Dussubieux, L.; Walder, H. Identifying American native and European smelted coppers with pXRF: A case study of artifacts from the Upper Great Lakes region. J. Archaeol. Sci. 2015, 59, 169-178. [CrossRef]

35. Brunetti, A.; Golosio, B.; Melis, M.G.; Mura, S. A high-quality multilayer structure characterization method based on X-ray fluorescence and Monte Carlo simulation. Appl. Phys. A 2014, 118, 497-504. [CrossRef]

36. Manso, M.; Schiavon, N.; Queralt, I.; Arruda, A.M.; Sampaio, J.M.; Brunetti, A. Alloy characterization of a 7th Century BC archeological bronze vase-Overcoming patina constraints using Monte Carlo simulations. Spectrochim. Acta Part B At. Spectrosc. 2015, 107, 93-96. [CrossRef]

37. Bottaini, C.E.; Brunetti, A.; Montero-Ruiz, I.; Valera, A.; Candeias, A.; Mirão, J. Use of Monte Carlo Simulation as a Tool for the Nondestructive Energy Dispersive X-ray Fluorescence (ED-XRF) Spectroscopy Analysis of Archaeological Copper-Based Artifacts from the Chalcolithic Site of Perdigões, Southern Portugal. Appl. Spectrosc. 2017, 72, 17-27. [CrossRef]

38. Giurlani, W.; Berretti, E.; Innocenti, M.; Lavacch, A. Coating Thickness Determination Using X-ray Fluorescence Spectroscopy: Monte Carlo Simulations as an Alternative to the Use of Standards. Coatings 2019, 9, 79. [CrossRef]

39. Trojek, T. Iterative Monte Carlo procedure for quantitative X-ray fluorescence analysis of copper alloys with a covering layer. Radiat. Phys. Chem. 2020, 167. [CrossRef]

40. Karydas, A. Application of a portable XRF spectrometer for the non-invasive analysis of museum metal artefacts. Ann. Chim. 2007, 97, 419-432. [CrossRef]

41. Sestieri, P.C. La necropoli preistorica di Paestum. Riv. Sci. Preisloriche 1946, 1, 245-266.

42. Sestieri, P.C. Nuovi risultati dagli scavi nella necropoli preistorica di Paestum. Riv. Sci. Preisloriche 1947, 2, $283-290$. 
43. Sestieri, P.C. Primi risultati degli scavi nella necropoli preistorica di Paestum. Rendiconli Accad. Archeol. Lellere Belle Arti Napoli 1946, 23, 251-308.

44. Voza, G. Ultimi scavi della necropoli del Gaudo. In Proceedings of the Atti Della IX Riunione Scientifica, Calabria, Italy, 6-8 April 1964; Istituto Italiano di Preistoria e Protostoria: Florence, Italy, 1965; pp. 265-274.

45. Pallottino, M. La Necropoli di Cerveteri; La Libreria dello Stato: Rome, Italy, 1939.

46. Pace, B.; Vighi, R.; Ricci, G.; Moretti, M. Cerveteri. Scavi di Raniero Mengarelli; Ulrico Hoepli: Milan, Italy, 1955.

47. Stefani, E. Gualdo Tadino: Scoperte varie. Not. Scavi 1935, 1935, 155-173.

48. Colini, A.M. Veio. Scavi nell'area della città e della necropolis. Not. Scavi 1919, 1919, 3-12.

49. Bianco Peroni, V. Die Schwerter in Italien: Le Spade Nell'Italia Continentale; Beck: Munich, Germany, 1970.

50. Buranelli, F.; Drago, L.; Paolini, L. La Necropoli di Casale del Fosso. In Le Necropoli Arcaiche di Veio: Giornata di Studio in Memoria di Massimo Pallottino; Pallottino, M., Bartoloni, G., Eds.; Università degli Studi di Roma "La Sapienza”, Dipartimento di scienze Storiche, Archeologiche e Antropologiche dell'antichità: Rome, Italy, 1997; pp. 63-83.

51. Ricciardi, L. La necropoli settentrionale di Vulci. resoconto di un'indagine bibliografica e d'archivio. Boll. Arte 1989, 58, $27-52$.

52. Ferretti, M. The investigation of ancient metal artefacts by portable X-ray fluorescence devices. J. Analyical At. Spectrom. 2014, 29, 1753-1766. [CrossRef]

53. Karydas, A.G.; Anglos, D.; Harith, M.A. Mobile Micro-XRF and LIBS Spectrometers for Diagnostic Micro-Analysis of Ancient Metal Objects. In Metals and Museums in the Mediterranean: Protecting, Preserving and Interpreting; Argyropoulos, V., Ed.; Department of Conservation of Antiquities and Works of Art: Athens, Greece, 2008; pp. 141-177.

54. Nørgaard, H.W. Portable XRF on Prehistoric Bronze Artefacts: Limitations and Use for the Detection of Bronze Age Metal Workshops. Open Archaeol. 2017, 3, 101-122. [CrossRef]

55. Castelle, M.; Dillmann, P.; Vega, E.; Blanc-Riehl, C.; Vilain, A.; Chastang, P.; Anheim, E. Seal the deal: An extensive study of European historical copper-based seal matrices using a multimodal protocol. J. Archaeol. Sci. 2020, 113, 105061. [CrossRef]

56. Mödlinger, M.; Calderon, E.d.O.; Haubner, R. Arsenic Loss During Metallurgical Processing of Arsenical Bronze. Archaeol. Anthropol. Sci. 2019, 11, 133-140. [CrossRef]

57. Lechtman, H. Arsenic Bronze: Dirty Copper or Chosen Alloy? A View from the Americas. J. Field Archaeol. 1996, 23, 477-514 [CrossRef]

58. Lechtman, H. The Production of Copper-Arsenic Alloys (Arsenic Bronze) by Cosmelting: Modern Experiment, Ancient Practice. J. Archaeol. Sci. 1999, 26, 497-526. [CrossRef]

59. Oudbashi, O.; Naseri, R.; Malekzadehet, M. Technical Studies on the Bronze Age Metal Artefacts from the Graveyard of Deh Dumen, South-Western Iran (Third Millennium BC). Archaeometry 2016, 58, 947-965. [CrossRef]

60. Chiavari, C.; Rahmouni, K.; Takenouti, H.; Joiret, S.; Vermaut, P.; Robbiola, L. Composition and electrochemical properties of natural patinasof outdoor bronze monuments. Electrochim. Acta 2007, 52, 7760-7769. [CrossRef]

61. Jones, C.; Duffy, C.; Gibson, A.; Terras, M. Understanding multispectral imaging of cultural heritage: Determining best practice in MSI analysis of historical artefacts. J. Cult. Herit. 2020, 45, 339-350. [CrossRef]

62. Tuttle, P. Conservation of the Bronze Cuirass and Helmet. J. Paul Getty Mus. J. 1982, 10, 141-144.

63. Stefani, E. Veio. Saggi E Scoperte Fortuite Nella Necropolis. Not. Scavi 1929, 1929, 326-349.

64. Humphreys, E. How to spot a fake. Mater. Today 2002, 5, 32-37. [CrossRef]

65. Drago Troccoli, L. Una coppia di principi nella necropoli di Casale del Fossa a Veio. In Dinamiche di Sviluppo delle Città Nell'Etruria Meridionale: Veio, Caere, Tarquinia Vulci, Proceedings of the Atti del XXIII Convegno di Studi Etruschi ed Italici, Roma, Veio, Cerveteri/Pyrgi, Tarquinia, Tuscania, Vulci, Viterbo, 1-6 Ottobre 2001; Paoletti, O., Ed.; IEPI: Pisa, Italy, 2005; Volume 23, pp. 87-124.

66. Molloy, B.; Mödlinger, M. The Organisation and Practice of Metal Smithing in Later Bronze Age Europe. J. World Prehistory 2020, 33, 169-232. [CrossRef]

67. De Marinis, R.C. Aspetti della metallurgia dell'età del Rame e dell'antica età del Bronzo nella penisola italiana. Riv. Sci. Preist. 2006, 56, 211-272.

68. Esposito, A.; Petitti, P.; Ferretti, M.; Gorghinian, A.; Rossi, F. The production of metal artefacts in Southern Etruria (Central Italy): Case studies from copper to Iron Age. STAR Sci. Technol. Archaeol. Res. 2019, 5, 64-84. [CrossRef]

69. Mödlinger, M. Body Armour in the European Bronze Age. In Prehistoric Warfare and Violence: Quantitative and Qualitative Approaches; Dolfini, A., Crellin, R., Horn, C., Uckelmann, M., Eds.; Springer: Cham, Switzerland, 2018; pp. 177-198. [CrossRef]

70. Chen, D.; Yang, Y.; Du, J.; Tang, X.; Luo, W. Alloy ratio and raw material sourcing of Warring States Period bronze bracelets in Huili County, Southwest China by pXRF and MC-ICP-MS. Herit. Sci. 2020, 8, 69. [CrossRef]

71. Heginbotham, A.; Bassett, J.; Bourgarit, D.; Eveleigh, C.; Glinsman, L.; Hook, D.; Smith, D.; Speakman, R.J.; Shugar, A.; Van Langh, R. The copper CHARM set: A new set of certified reference materials for the standardization of quantitative X-ray fluorescence analysis of heritage copper alloys. Archaeometry 2015, 57, 856-868. [CrossRef]

72. Roxburgh, M.A.; Heeren, S.; Huisman, D.J.; van Os, B.J.H. Non-Destructive Survey of Early Roman Copper-Alloy Brooches Using Portable X-Ray Fluorescence Spectrometry. Archaeometry 2019, 61, 55-69. [CrossRef]

73. Zararsiz, A.; Zimmermann, T. The Missing Jigsaw Piece-Pxrf Bulk Analysis of the Karaburun Dagger and Some General Considerations on Metalwork in Early Bronze Age Western Anatolia. Cedrus 2020, 8, 65-74. [CrossRef] 